\title{
Understanding of Social Studies Teachers on the Scientific Approach
}

\author{
Mamat Ruhimat \\ Department of Geography Education, Faculty of Social Sciences Education, Universitas Pendidikan Indonesia, Indonesia
}

Received December 13, 2019; Revised September 9, 2020; Accepted September 29, 2020

\section{Cite This Paper in the following Citation Styles}

(a): [1] Mamat Ruhimat , "Understanding of Social Studies Teachers on the Scientific Approach," Universal Journal of Educational Research, Vol. 8, No. 11B, pp. 5677 - 5685, 2020. DOI: 10.13189/ujer.2020.082201.

(b): Mamat Ruhimat (2020). Understanding of Social Studies Teachers on the Scientific Approach. Universal Journal of Educational Research, 8(11B), 5677 - 5685. DOI: 10.13189/ujer.2020.082201.

Copyright $\odot 2020$ by authors, all rights reserved. Authors agree that this article remains permanently open access under the terms of the Creative Commons Attribution License 4.0 International License

\begin{abstract}
This study aims to analyze the level of social studies teacher's understanding of scientific learning approaches. The subjects of this study were 60 junior high school social studies teachers in Bandung, Indonesia. This research uses survey design. Data collection uses questionnaires. Data were analyzed using one-way ANOVA with IBM SPSS 22. The findings indicate that social studies teachers have understood the mechanism of scientific learning in a moderate level. Some of the answers to questions show an understanding of the stages of social science learning in junior high schools in Bandung. The response confirms that they have understood the mechanism of scientific learning with a moderate level of understanding. Although the majority of respondents have the low understanding of the four stages of scientific learning, almost all research questions answered by teacher respondents are appropriate by scientific standards. This result can practically be a direction for policy makers to formulate teacher education which does not merely emphasize the pedagogical and professional aspects in terms of students' mastery and teaching materials, but also deepens epistemological aspects and scientific mechanisms to broaden scientific fundamentals in classroom.
\end{abstract}

Keywords Social Studies, Scientific Approach, Teacher Understanding

\section{Introduction}

The scientific learning model provides broad opportunities for students to obtain knowledge independently based on the scientific method (Ayuni, 2015). Students are trained as if they are scientists who conduct scientific investigations. On the other hand, a scientific approach is positioned as a scientific learning process that is expected to develop scientific attitudes. Scientific inquiry or research includes several stages namely identifying problems, asking questions/submitting hypotheses, making observations, organizing and processing data, drawing conclusions, and publishing the results to others (Yani, 2014).

Knowledge of scientific inquiry in the world of science has developed rapidly. Methods of inquiry have contributed significantly to the development of science in the last few decades. In the world of education, most studies focus on the method and development of scientific inquiry in the field of science teaching, where inquiry is considered more verifiable, making it easier for science teachers to explain and make students easier to understand (Bybee, 2006; Penuel et al., 2011; Ketpichainarong et al., 2010; Peters \& Kitsantas, 2010; Demir \& Abell, 2010; Peters, 2010; Dudu \& Vhurumuku, 2012; Hussain et al., 2011). In contrast, understanding and methods in social sciences are still lacking, along with the incoherence between the methods offered and the possible biased results in several contexts. Others have diverse perspectives on effective methods of scientific inquiry in social science, such as independent inquiry (Todd et al., 2004). An exception is obtained from deMarrais and Lapan (2003) who offer methods in teaching scientific inquiry for teachers in the classroom. The lack of effective means and understanding of scientific inquiry in social science has 
long pushed Tom (1985) to offer ideas that are teacher-oriented inquiry in classroom teaching.

Teacher performance is influenced by their educational background, which means social studies teachers with appropriate backgrounds will teach better than social studies teachers who have different educational backgrounds (Sung \& Yang, 2013; Cury, 2007). The educational background of the teacher also determines the quality of teaching. Pre-service subject teachers are extrinsically motivated in choosing study programs and have positive experience in learning than pre-service class teachers (Rogošić, 2018).

All stages of scientific inquiry are applied in the teaching and learning process. The implementation of scientific inquiry is adjusted to the essential scope of each subject. Even every teacher has a unique teaching style even though they apply the same theory. The teaching style is also influenced by the teacher's pedagogical content knowledge, which is strongly influenced by the research subject's knowledge of learning material and teaching orientation (Gastaldo, Homem-de-Mello, \& Leal, 2016). Therefore, teacher understanding in a scientific approach must continue to be improved so that the learning process applied can achieve the expected goals (Wanzek et al., 2015). Scientific inquiry is not only owned by natural sciences, but also social sciences and other scientific disciplines. The stages of learning for the process of science skills in the 2013 curriculum have been reduced to observing, asking, experimenting, associating, and communicating (Kemendikbud, 2013) All subjects can apply the scientific approach during the teaching and learning process based on research. Familiarizing students with the research process early is expected to be able to shape their scientific character. School as an educational environment is a place to build the character of the younger generation. The format of character education in schools is integrated into teaching and learning activities, school culture, extracurricular activities, and daily activities in home and in the community (Kemendiknas, 2010). Building scientific character in students certainly requires a process of habituation early on in their lives in order to become a culture. Character as a special value-good (knowing good, wanting good, acting good, doing good, and having a good effect on the environment) is internalized and reflected in behavior (Kemendiknas, 2010).

The study of the social science teacher's understanding of scientific inquiry is very important in order to increase the literacy of students' abilities in scientific inquiry, and negate scientific biases or pseudoscience in the classroom (Fraknoi, 2003). Furthermore, Fraknoi (2003) emphasized that scientific understanding needs to be emphasized in students in the classroom because biases and pseudoscience are in important subjects such as physics and biology where there is a tendency to reject science because of the effects of religious and creationist teachings.
Likewise, Berkman and Plutzer (2011) highlight the need for an understanding of scientific inquiry to eliminate pseudoscience. Meanwhile, Lilienfeld et al. (2012) asserted that scientific thought has a major contribution in understanding students in science. On this basis, and by looking at the teacher-oriented inquiry offered by Tom (1985), this study seeks to analyze the level of teacher understanding of the scientific approach in learning and teaching social studies in junior high schools in Bandung, Indonesia.

\section{Literature Review}

\subsection{Learning Process}

Learning is a process carried out by individuals to obtain overall changes in behavior, as a result of interactions between individuals and their environment (Surya, 2013). The learning process will continue to be a human need because not all human needs can be met through habits and instincts. Learning is a system that includes many interrelated components. Research in the learning process is very important to do, so learning can adapt to dynamic conditions (Shanmugam \& Mee, 2017). Learning can be defined as a system or a process of educating students, which is planned or designed, implemented, and evaluated systematically to help students achieve learning goals effectively and efficiently. The result of learning in general is a change in student behavior (Riswanto. A, 2019). The learning process is not just transferring knowledge from an adult to an adult, but must be realized in the form of behavior change. Behavior that results from full learning includes cognitive, affective, conative, and motoric aspects (Surya, 2013). There are many types of learning. According to Gagne (1985), there are eight types of learning, namely signal learning, stimulus response learning, chaining learning, verbal association learning, discrimination learning, concept learning, rule learning, problem solving learning. The learning process should also present the involvement of student and teacher. The teacher is one of the important actors in the learning process. However, this does not mean that all learning problems must be borne by the teacher. Teachers will not be able to have optimal performance without the support of other parties, including students, parents, government, and society (Surya, 2013). Collaboration between teachers also has a significant effect on the professionalism of each teacher (Hongboontri \& Jantayasakorn, 2016). Therefore, learning and teaching are complementary. Both are activities that cannot be separated from each other.

\subsection{Social Sciences}

Social Sciences is the study of the interrelations of social sciences in examining social phenomena and problems that 
occur in society; it can complement the abilities of everyone in their social life, especially those whose work is directly related to the community (Sumaatmadja, 1984). Social science is also a subject that forms students to build good communication with others in their social lives and provide knowledge, skills, and values that can be applied in social life (Iulbrahimoğlu, 2018). in present, the term Social Sciences is increasingly popular as it is incorporated into school curricula in Indonesia. Social Sciences is an integration of the sciences of science and humanities to improve the competencies of citizens. Through social programs, social sciences provide a picture of coordinated and systematic learning such as the disciplines of anthropology, religion, and sociology, as well as content in humanities, mathematics, and natural sciences (NCSS (National Council for Social Studies), 1994). Education will be meaningful when considering the needs and aspirations of developing societies, not only developing students' physical and mental growth (Krishnan et al., 2017). Social Sciences in Indonesia are the main subjects taught from elementary school to junior high school in an integrated manner. In the high school level, subjects continue to be taught, but not integrated as in primary and junior high schools. Social science is a science that uses an integrative approach of several subjects so that subjects become meaningful to students and to prevent overlapping (Somantri, 2001). There are several principles for making guidelines in teaching and learning of social science to be stronger and meaningful, namely: learning to teach social science will be stronger when meaningful, learning to teach social science will be stronger when integrated, learning to teach social science will be strong if based on values, learning to teach social science will be stronger if it is challenging, and learning to teach social science will be stronger when active.

\subsection{Scientific Approach}

The scientific learning approach in Indonesia is currently increasing in popularity in line with the implementation of the 2013 Curriculum. The scientific approach also recommended by UNESCO relates to the concept of the four pillars of education (Delors et al., 1996). The four pillars of education consist of learning to know, learning to do, learning to live together, and learning to be. Research on school effectiveness provides direction for school management to further improve the quality of learning based on empirically tested theories (Azkiyah, 2017). The scientific learning model uses the guided discovery approach, which is expected to help students learn about how to learn (Carin \& Sund, 1989). It is hoped that the transfer of knowledge from the teacher to students is not in a conventional model such as lecture; however, the learning process must facilitate students to find knowledge (Rostika \& Prihantini, 2019). Students are no longer positioned as a passive party, but the subject of teaching and learning. In fact, in student-centered learning, students are empowered to choose learning content and methods to be used in learning that content (Yap, Neo, \& Neo, 2016).

Improving information technology provides challenges to the application of scientific approaches in learning. The use of ICT is able to change communication patterns between teachers and students to be open and not limited to the classroom (Kubiatko, 2017). Of course, this must be supported by the teacher's capacity in training students to use various kinds of equipment. Learning with a scientific approach is a process that is designed so that students are actively able to develop concepts, rules, or principles through five stages. These stages are observing, formulating problems, proposing or formulating hypotheses, collecting data using several techniques, analyzing data, drawing conclusions and communicating concepts, which are the principles found during the learning process. These abilities are needed by students to improve work skills in the digital world with a very large amount of data (Cheng \& Chang, 2019). The advantage gained from learning through a scientific approach lies in the experience given to students in finding and building knowledge, so they will be able to think critically, because they have been directly involved with real objects.

The ability of the scientific process is essential to practice critical thinking skills, since early students have been accustomed to observing, interpreting, classifying, predicting, communicating, hypothesizing, designing experiments, applying concepts, and asking questions (Rustaman, 1992). The scientific learning approach, in fact is closely related to discovery learning, inquiry learning, problem-based learning, and project-based learning. Discovery learning leads to the discovery of something based on the process of inquiry conducted by students, whereas inquiry learning does not always lead to discovery; but rather leads to the process of disclosing the dynamics of an event and / or phenomenon (Supriyono, 2001). Problem-based learning can be collaborated with scientific learning. Problem-based learning allows students to be active and brave to pursue solutions to the problems faced (Yani, 2014). The implementation of a scientific approach requires changes in the culture of learning, which must be different from conventional learning. Some other approaches that are considered suitable for scientific learning are problem-based learning, project-based learning, inquiry and group inquiry. In a scientific approach, the teacher's main role remains, as a facilitator who directs and guides students. In principle, it is the implementation of guided discoveries. The implementation of the guided discovery method can increase student learning activities (Yulida, Kausar, \& Andriani, 2016).

\section{Method}

The research method used was a survey method by 
collecting data through questionnaires. Research location is Bandung City, West Java Province, Indonesia. The determination of the research location considers the collaboration between the university and the city government in developing education in the junior high school level. The method applied in this study was a survey that focused on identifying social studies teachers' understanding of scientific learning approaches in the junior secondary school level in Bandung, West Java Province, Indonesia.

The number of respondents was 60 junior high school social studies teachers in Bandung, consisting of 33 public junior high school teachers (55\%) and 27 private junior high school teachers $(45 \%)$. Data collection is done through test instruments. Each respondent was asked to answer the questions contained in the instrument. The scientific approach has five stages and each stage is tested with five questions making a total of 25 questions. Respondents get +1 if they answer correctly and 0 if they don't answer or answer incorrectly. Data analysis was performed with Analysis of Variance (ANOVA) using the IBM SPSS 21 application for Windows. The use of ANOVA aims to explore information through comparison of the average level of understanding of teachers in learning using a scientific approach.

\section{Results}

Demographic characteristics of respondents showed that the majority were women as many as 33 respondents (55\%), compared to men as many as 27 (45). In terms of age, the majority of respondents aged 30-50 years were 44 people or $73.3 \%$, followed by respondents aged $>50$ as many as 11 people $(18.4 \%)$. In terms of education, almost all are undergraduate graduates of 58 people or $97 \%$ with the majority having experience between 10-20 years as many as 35 people or $58.3 \%$ (Table 1 ).

Table 1. Demographic characteristics of respondents

\begin{tabular}{ccc}
\hline Category & Frequency & Percentage \\
\hline Gender: & & \\
\hline Male & 27 & 45 \\
\hline Female & 33 & 55 \\
\hline Age: & & \\
\hline$<30$ & 5 & 8.3 \\
\hline $30-50$ & 44 & 73.3 \\
\hline$>50$ & 11 & 18.4 \\
\hline Education: & & \\
\hline Undergraduate & 58 & 2 \\
\hline Master & 2 & 21.7 \\
\hline Experience: & & 58.3 \\
\hline$<10$ & 13 & 20 \\
\hline $10-20$ & 35 &
\end{tabular}

Next, data obtained from respondents through filling in the test instrument are presented in graphical form which can be seen in Figure 1. Figure 1 is the total score of all 60 respondents. The maximum score for each stage is 5 (all questions are answered correctly) and the minimum score is 0 (all questions are answered incorrectly). Respondents' scores for each stage in the scientific approach are added up, producing scores ranging between 300 and 0 (all respondents answered correctly or all respondents answered incorrectly).

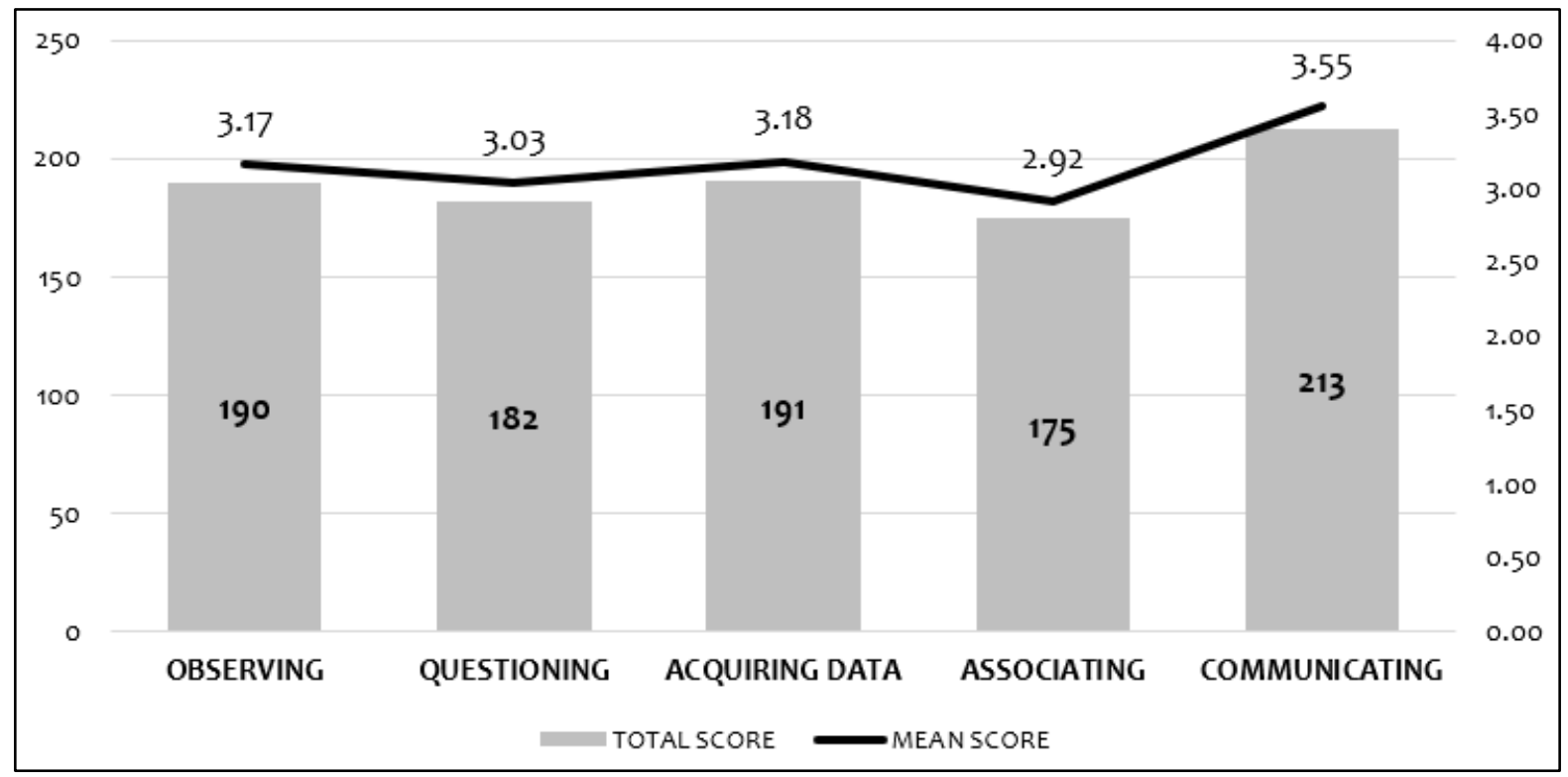

Figure 1. Level of Teacher's Understanding of Scientific Approaches 
Based on Figure 1, respondents have different levels of understanding for each stage of the scientific approach. The graph in Figure 1 shows two groups of data, namely the total score and the average score. The total score (indicated by the form of a bar in the graph) is the total score obtained from 60 respondents. The average score (indicated by the shape of the line on the graph) is the average score obtained from 60 respondents. The lowest total score of this understanding is the associating stage (total score of 175), while the highest total score is the communication stage (total score of 213). The stages of observing, asking, and collecting data each obtained the score of 190,182 , and 191. To interpret the graph, it is necessary to calculate the maximum score and the minimum score for each stage. The maximum score is 300 and the minimum score is 0 . The categories for each score are low (0-100), moderate (101-200) and high (201-300). Based on these calculations, it can be concluded that respondents' understanding of the scientific approach in social studies learning falls into the medium category. The average score in Figure 1 shows a moderate level of understanding for each stage in the scientific approach. The score in each step is 3.17 (observing), 3.03 (asking), 3.18 (obtaining data), 2.92 (associating), and 3.55 (communicating). The average score ranges from 0-5. Based on the average score in Figure 1, it can be concluded that the level of respondents' understanding of the scientific approach is moderate. The score of each level of understanding of respondents is specifically shown in Figure 2.

Figure 2 showed five stages in scientific learning. Each stage presented data from the level of understanding of respondents into three groups, namely high, medium and low. Each respondent has answered five questions about the stage of observing. The maximum score is 5 and the minimum score is 0 . Based on the range of scores, the level of understanding of respondents is categorized to low (0-2), moderate (3) and high (4-5). Based on the graph in Figure 2, most respondents have a high understanding of obtaining data $(47 \%)$ and the communication stage $(53 \%)$. However, the majority of respondents have the low understanding of observing (43\%), asking questions (50\%) and associating $(28 \%)$. Data shows that teachers only understand two of the five stages in scientific learning.

Then, the data are processed using the Analysis of Variance (ANOVA) technique on the IBM SPSS 21 application. The data analysis stage uses the normality test, homogeneity test, ANOVA test, and multiple comparison test using Tukey HSD. The results of the normality and homogeneity test can be seen in table 2 . The results of normality and homogeneity tests have met the requirements for data analyzed using ANOVA techniques.

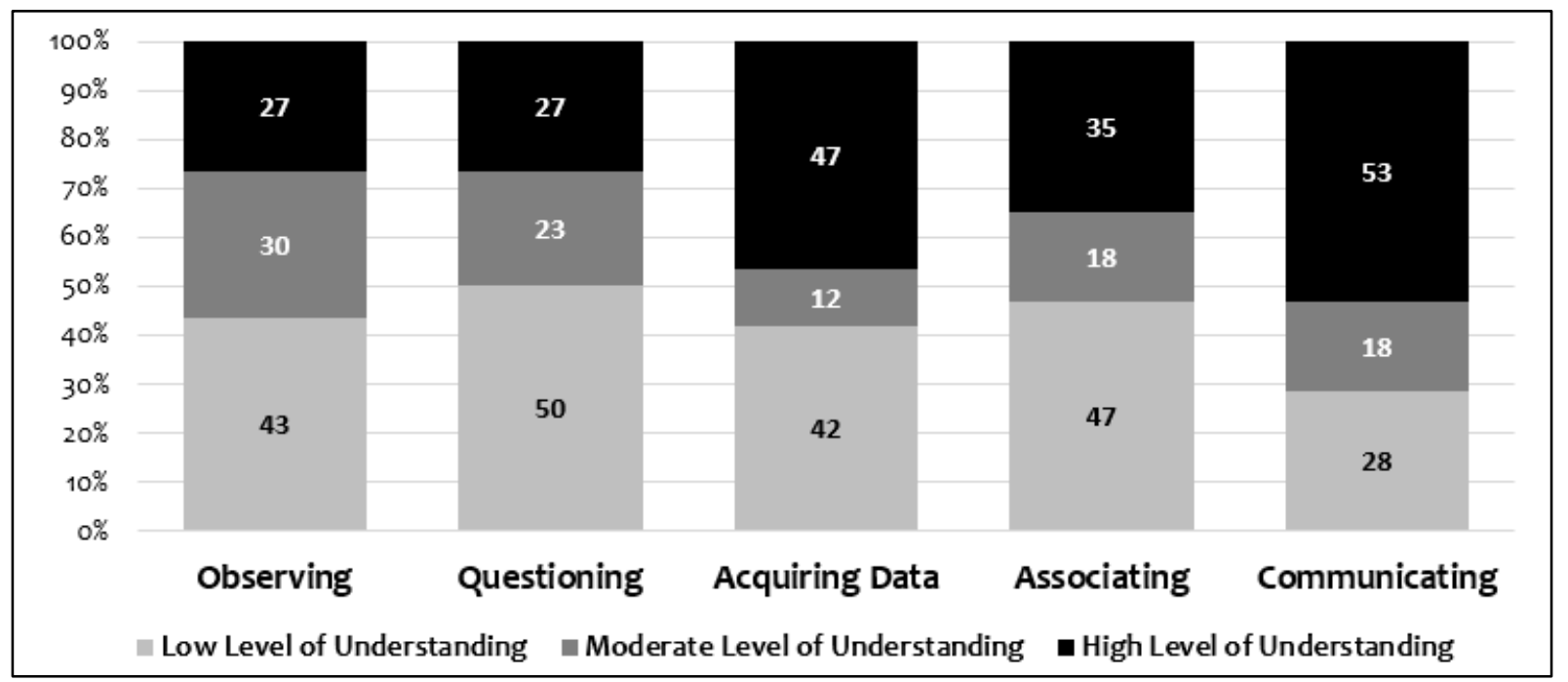

Figure 2. Data Distribution of Teacher's Understanding Level (in Percentage)

Table 2. The Normality and Homogeneity Tests

\begin{tabular}{|c|c|c|c|c|c|}
\hline \multirow[b]{2}{*}{ No } & \multirow{2}{*}{$\begin{array}{c}\text { Scientific Learning } \\
\text { Stages }\end{array}$} & \multicolumn{2}{|c|}{ Normality } & \multicolumn{2}{|c|}{ Homogeneity } \\
\hline & & $\begin{array}{c}\text { Shapiro-Wilk } \\
\text { Significance }\end{array}$ & Interpretation & $\begin{array}{l}\text { Levene Statistical } \\
\text { Significance }\end{array}$ & Interpretation \\
\hline 1 & Observe & 0.180 & Normal & \multirow{5}{*}{0.119} & \multirow{5}{*}{ Homogen } \\
\hline 2 & Asking & 0.117 & Normal & & \\
\hline 3 & Obtaining Data & 0.060 & Normal & & \\
\hline 4 & Associate & 0.310 & Normal & & \\
\hline 5 & Communicate & 0.400 & Normal & & \\
\hline
\end{tabular}


Table 3. Analysis of Variance (ANOVA)

\begin{tabular}{cccccc}
\hline $\begin{array}{c}\text { Understanding } \\
\text { Level }\end{array}$ & $\begin{array}{c}\text { Sum of } \\
\text { Squares }\end{array}$ & df & Mean Square & F & Sig. \\
\hline Among groups & 30.213 & 4 & 7.553 & 4.160 & 0.003 \\
\hline Among groups & 535.667 & 295 & 1.816 & & \\
\hline Total & 565.880 & 299 & & & \\
\hline
\end{tabular}

ANOVA test results as presented in Table 3 showed that the significance value is 0.003 . a significance value of 0.003 is smaller than 0.05 so the ANOVA test results indicate a difference in the average level of understanding between the five stages in the scientific learning approach.

Table 4 shows the comparison data between teacher understanding in each stage in the scientific learning approach. Each stage is compared with other stages to determine the level of difference. If the significance value is below 0.05 , the average understanding is significantly different from the comparison stage. However, if the significance value is $>0.05$, the average understanding in a stage is not different from the stage that is being compared (Table 5).

Table 4. Multiple Comparisons

\begin{tabular}{|c|c|c|c|c|c|c|}
\hline \multicolumn{7}{|c|}{ Understanding Level } \\
\hline \multirow{3}{*}{$\begin{array}{c}\text { (I) Stages in Scientific } \\
\text { Learning }\end{array}$} & \multicolumn{4}{|c|}{\begin{tabular}{|c|} 
Tukey HSD \\
\end{tabular}} & & \\
\hline & \multirow{2}{*}{$\begin{array}{c}\text { (J) Stages in Scientific } \\
\text { Learning }\end{array}$} & \multirow{2}{*}{$\begin{array}{c}\text { Average } \\
\text { Difference (I-J) }\end{array}$} & \multirow{2}{*}{ Std. Error } & \multirow{2}{*}{ Sig. } & \multicolumn{2}{|c|}{ 95\% Confidence Interval } \\
\hline & & & & & Lower Bound & Upper Bound \\
\hline \multirow{4}{*}{ Observing } & Asking & 0.150 & 0.246 & 0.973 & -0.53 & 0.83 \\
\hline & Obtaining & -0.383 & 0.246 & 0.526 & -1.06 & 0.29 \\
\hline & Associating & -0.117 & 0.246 & 0.990 & -0.79 & 0.56 \\
\hline & Communicating & $-.0750^{*}$ & 0.246 & 0.021 & -1.43 & -0.07 \\
\hline \multirow{4}{*}{ Asking } & Observing & -0.150 & 0.246 & 0.973 & -0.83 & 0.53 \\
\hline & Obtaining & -0.533 & 0.246 & 0.195 & -1.21 & 0.14 \\
\hline & Associating & -0.267 & 0.246 & 0.815 & -0.94 & 0.41 \\
\hline & Communicating & $-0.900^{*}$ & 0.246 & 0.003 & -1.58 & -0.22 \\
\hline \multirow{4}{*}{ Obtaining } & Observing & 0.383 & 0.246 & 0.526 & -0.29 & 1.06 \\
\hline & Asking & 0.533 & 0.246 & 0.195 & -0.14 & 1.21 \\
\hline & Associating & 0.267 & 0.246 & 0.815 & -0.41 & 0.94 \\
\hline & Communicating & -0.367 & 0.246 & 0.570 & -1.04 & 0.31 \\
\hline \multirow{4}{*}{ Associating } & Observing & 0.117 & 0.246 & 0.990 & -0.56 & 0.79 \\
\hline & Asking & 0.267 & 0.246 & 0.815 & -0.41 & 0.94 \\
\hline & Obtaining & -0.267 & 0.246 & 0.815 & -0.94 & 0.41 \\
\hline & Communicating & -0.633 & 0.246 & 0.078 & -1.31 & 0.04 \\
\hline \multirow{4}{*}{ Communicating } & Observing & $0.750^{*}$ & 0.246 & 0.021 & 0.07 & 1.43 \\
\hline & Asking & $0.900^{*}$ & 0.246 & 0.003 & 0.22 & 1.58 \\
\hline & Obtaining & 0.367 & 0.246 & 0.570 & -0.31 & 1.04 \\
\hline & Associating & 0.633 & 0.246 & 0.078 & -0.04 & 1.31 \\
\hline
\end{tabular}

Table 5. Level of Teacher Understanding

\begin{tabular}{|c|c|c|c|}
\hline \multicolumn{3}{|c|}{ Tukey HSD $^{\mathbf{a}}$} \\
\hline \multirow{2}{*}{ Scientific Learning Stages } & \multirow{2}{*}{} & 1 & 2 \\
\cline { 2 - 4 } & & 2.80 & \\
\hline Observing & 60 & 2.65 & 3.18 \\
\hline Asking & 60 & 3.18 & 2.92 \\
\hline Obtaining & 60 & 2.92 & 3.55 \\
\hline Associating & 60 & 0.195 & 0.078 \\
\hline Communicating & 60 & \\
\hline Sig. & & \\
\hline \multicolumn{2}{|c|}{ Means for groups in homogeneous subsets are displayed. } \\
\hline
\end{tabular}




\section{Conclusions}

In general, social studies teachers in junior high schools in Bandung have understood the mechanism of scientific learning with a moderate level of understanding. Although most respondents have the low understanding of the four stages of scientific learning, almost all research questions are answered by teacher respondents. Most teachers have started to apply scientific learning in the teaching and learning process. Measurement of learning outcomes is also no longer oriented to the assessment of results, but began to aim in assessing the learning process. Observing activities, class discussions, and project assignments have begun to be understood and applied in the teaching and learning process. The findings from this study are very encouraging because it indicates that social studies teachers in Bandung are ready to apply the scientific learning approach in order to understand and apply the approach the directions of the 2013 curriculum.

Learning with a scientific approach is an effort to improve the effectiveness of social studies learning in class. But the scientific approach is still not understood by many social studies teachers, especially social studies teachers who teach in remote places. There is still a misunderstanding of social studies teachers in the application of scientific learning. Therefore, this research is scientific evidence that shows that social studies teachers need to be encouraged to improve their pedagogical competencies, especially in applying scientific approaches. The role of government and scientists in the field of education is needed to overcome this problem. Efforts that can be made are to increase the intensity of training for social studies teachers and hold a Group Discussion Forum for social studies teachers who can deepen their understanding of the scientific approach.

\section{REFERENCES}

[1] Ayuni, F. N. (2015). Pemahaman Guru terhadap Pendekatan Saintifik (Scientific Approach) dalam Pembelajaran Geografi. Jurnal Pendidikan Geografi Gea, 15(2), 1-7.

[2] Azkiyah, S. N. (2017). Educational effectiveness research as the knowledge base of improving education. Pertanika Journal of Social Sciences and Humanities, 25(3), 10191038.

[3] Berkman, M. B., \& Plutzer, E. (2011). Defeating creationism in the courtroom, but not in the classroom. Science, 331(6016), 404-405.

[4] Bybee, R. W. (2006). Scientific inquiry and science teaching. In Scientific inquiry and nature of science (pp. 1-14). Springer, Dordrecht.

[5] Carin, A. A., \& Sund, R. B. (1989). Science: Activity programs in education; Study and teaching (Elementary); Handbook, Manuals, etc. 2nd Edition. Columbus: Merrill
Publishing Company.

[6] Cheng, S., \& Chang, S.-L. (2019). An Innovative Assessment Method to Establish Employability Map Based on Students' Learning Portofolio. Problems of Education in the 21st Century, 77(2), 209-227.

[7] Cury, A. (2007). Brilliant Parents Fascinating Teachers. (J. Susanto, Ed.). Jakarta: PT. Gramedia Pustaka Utama.

[8] Delors, J., Mufti, I. Al, Amagi, I., Carneiro, R., Chung, F., Geremek, B., ... Nanzhao, Z. (1996). Learning: The Treasure Within. Paris: UNESCO.

[9] deMarrais, K. B., \& Lapan, S. D. (Eds.). (2003). Foundations for research: Methods of inquiry in education and the social sciences. Routledge.

[10] Demir, A., \& Abell, S. K. (2010). Views of inquiry: Mismatches between views of science education faculty and students of an alternative certification program. Journal of Research in Science Teaching, 47(6), 716-741.

[11] Dudu, W. T., \& Vhurumuku, E. (2012). Teachers' practices of inquiry when teaching investigations: A case study. Journal of Science Teacher Education, 23(6), 579-600.

[12] Fraknoi, A. (2003). Dealing with astrology, UFOs, and faces on other worlds: a guide to addressing astronomical pseudoscience in the classroom. Astronomy Education Review, 2(2), 150

[13] Gagne, R. M. (1985). The Conditions of Learning and Theory of Instructions. New York: Holt, Rinehart and Winston.

[14] Gastaldo, B. C., Homem-de-Mello, P., \& Leal, S. H. (2016). The Effect of Teacher Instructions on Pre-Service Teacher's Development of Pedagogical. Problems of Education in the 21st Century, 73, 45-61.

[15] Hongboontri, C., \& Jantayasakorn, M. (2016). Cultures of teaching: Mapping the teacher professional development terrain. Pertanika Journal of Social Sciences and Humanities, 24(3), 1139-1163.

[16] Hussain, A., Azeem, M., \& Shakoor, A. (2011). Physics teaching methods: scientific inquiry vs traditional lecture. International Journal of Humanities and Social Science, 1(19), 269-276.

[17] Iulbrahimoğlu, Z. (2018). Middle School Students' Conceptual Perceptions of the Social Studies Course, and Their Transfer of the Outcomes to Daily Life. Journal of Educational Research, 0(0), 1-9.

[18] Justice, C., Warry, W., Cuneo, C., Inglis, S., Miller, S., Rice, J., \& Sammon, S. (2002). A grammar for inquiry: Linking goals and methods in a collaboratively taught social sciences inquiry course. The Alan Blizzard Award Paper: The Award Winning Papers, $\mathrm{n} 1$.

[19] Kemendikbud RI (Kementerian Pendidikan dan Kebudayaan Republik Indonesia). (2013). Regulation of the Minister of Education and Culture Number 81A Year 2013 regarding Curriculum Implementation. Jakarta: Kemendikbud RI.

[20] Kemendiknas RI (Kementerian Pendidikan Nasional Republik Indonesia). (2010). Desain Induk Pendidikan Karakter (Master Design of Character Education). Jakarta: 
Kementerian Pendidikan Nasional Republik Indonesia.

[21] Ketpichainarong, W., Panijpan, B., \& Ruenwongsa, P. (2010). Enhanced learning of biotechnology students by an inquiry-based cellulase laboratory. International Journal of Environmental and Science Education, 5(2), 169-187.

[22] Krishnan, C., Goel, R., Singh, G., Bajpai, C., Malik, P., \& Sahai, S. (2017). Emotional intelligence: A study on academic professionals. Pertanika Journal of Social Sciences and Humanities, 25(4), 1555-1568.

[23] Kubiatko, M. (2017). Are ICT being Used Correctly? Small Reflection about Correct Using of ICT in Education. Problems of Education in the 21st Century, 75(1), 4-5. Retrieved from http://journals.indexcopernicus.com/abstrac t.php?icid=1232389

[24] Lilienfeld, S. O., Ammirati, R., \& David, M. (2012). Distinguishing science from pseudoscience in school psychology: Science and scientific thinking as safeguards against human error. Journal of School Psychology, 50(1), 7-36.

[25] Mulyana, E. (2015). Comparison of Effectiveness of Learning Cooperative Integrated Reading and Composition, Group Investigation, and Team Games Tournament on Understanding of Social Sciences Concepts. Universitas Pendidikan Indonesia. Retrieved from http://repository.upi. $\mathrm{edu} / 22423 /$

[26] NCSS (National Council for Social Studies). (1994). Curriculum Standard for Social Studies. Washington: Expectation of Excellence.

[27] Penuel, W. R., Gallagher, L. P., \& Moorthy, S. (2011). Preparing teachers to design sequences of instruction in earth systems science: A comparison of three professional development programs. American Educational Research Journal, 48(4), 996-1025.

[28] Peters, E. E. (2010). Shifting to a student-centered science classroom: An exploration of teacher and student changes in perceptions and practices. Journal of Science Teacher Education, 21(3), 329-349.

[29] Peters, E., \& Kitsantas, A. (2010). The effect of nature of science metacognitive prompts on science students' content and nature of science knowledge, metacognition, and selfregulatory efficacy. School Science and Mathematics, 110(8), 382-396.

[30] Riswanto, A., \& Aryani, S. (2017). Learning motivation and student achievement: description analysis and relationships both. COUNSEDU: The International Journal of Counseling and Education, 2(1), 42.

[31] Rogošić, S. (2018). Differences in Social Background, Study Choice Motivation and Higher Education Experience Between Pre-Service Class Teachers and Pre-Service Subject Teachers. Problems of Education in the 21st Century, 76(5), 706-719. Retrieved fromhttp://oaji.net/articles/2017/ 457-1540320405.pdf

[32] Rostika, D., \& Prihantini, P. (2019). Pemahaman Guru tentang Pendekatan Saintifik dan Implikasinya dalam Penerapan Pembelajaran di Sekolah Dasar. Eduhumaniora: Jurnal Pendidikan Dasar, 11(1), 86-94. https://doi.org/http:/ /dx.doi.org/10.17509/eh.v11i1.14443
[33] Rustaman, N. Y. (1992). Research Report on the Development and Validation of Measuring Science Process Skills in 9-Year Basic Education in preparation for the implementation of the 1994 Curriculum. Universitas Pendidikan Indonesia.

[34] Shanmugam, S. K. S., \& Mee, L. S. (2017). Barriers of implementing action research among Malaysian teachers. Pertanika Journal of Social Sciences and Humanities, 25(4), 1651-1666.

[35] Shih, J. L., Chuang, C. W., \& Hwang, G. J. (2010). An inquiry-based mobile learning approach to enhancing social science learning effectiveness. Journal of Educational Technology \& Society, 13(4), 50-62.

[36] Somantri, M. N. (2001). Menggagas Pembaharuan Pendidikan IPS (Initiating Reform in Social Studies Education). Bandung: Remaja Rosdakarya.

[37] Sumaatmadja, N. (1984). Metodologi Pengajaran Ilmu Pengetahuan Sosial (The Methodology of Social Studies Teaching). Bandung: Alumni.

[38] Sung, P. F., \& Yang, M. L. (2013). Exploring disciplinary background effect on social studies teachers' knowledge and pedagogy. Journal of Educational Research, 106(1), 77-88.

[39] Supriyono, A. (2001). Cooperative Learning. Yogyakarta: Pustaka Pelajar.

[40] Surya, M. (2013). Psikologi Guru, Konsep dan Aplikasi (The Psychology of Teachers, Concepts, and Application). Bandung: Alfabeta.

[41] Tandilling, E. (2012). Development of Instruments for Measuring Mathematical Communication, Mathematical Understanding, and Self-Regulated Learning in Students in Mathematics Learning in High Schools. Jurnal Penelitian Pendidikan, 13(1), 24-31. https://doi.org/10.1024/1422-491 $7 / \mathrm{a} 000459$

[42] Todd*, M., Bannister, P., \& Clegg, S. (2004). Independent inquiry and the undergraduate dissertation: perceptions and experiences of final-year social science students. Assessment \& Evaluation in Higher Education, 29(3), 335-355.

[43] Todd*, M., Bannister, P., \& Clegg, S. (2004). Independent inquiry and the undergraduate dissertation: perceptions and experiences of final-year social science students. Assessment \& Evaluation in Higher Education, 29(3), 335-355.

[44] Tom, A. R. (1985). Inquiring into inquiry-oriented teacher education. Journal of teacher education, 36(5), 35-44.

[45] Wanzek, J., Kent, S. C., Vaughn, S., Swanson, E. A., Roberts, G., \& Haynes, M. (2015). Implementing Team-Based Learning in Middle School Social Studies Classes. Journal of Educational Research, 108(4), 331-344.

[46] Yani, A. (2014). Mindset Kurikulum 2013 (The Mindset of Curriculum 2013). Bandung: Alfabeta.

[47] Yap, W. L., Neo, M., \& Neo, T. K. (2016). The impact of the role of teacher and balance of power in transforming conventional teaching to learner-centered teaching in Malaysian institution of higher education. Pertanika Journal of Social Sciences and Humanities, 24(4), 1849-1868.

[48] Yulida, R., Kausar, K., \& Andriani, Y. (2016). Utilization of 
Learning Models in Improving Student Learning Activities and Results in Agricultural Extension and Communication
Courses. Mimbar Pendidikan: Jurnal Indonesia Untuk Kajian Pendidikan, 1(2), 189-200. 